\begin{abstract}
Yori Akbar Setiyawan
Departemen Arkeologi, Fakultas IImu Budaya Universitas Gadjah Mada, Jalan Sosio-Humaniora, Bulaksumur, Yogyakarta 55281 yori.akbar.s@mail.ugm.ac.id
\end{abstract}

Diterima 3 Maret 2021

Direvisi 28 April 2021

Disetujui 28 April 2021

\section{LATAR BELAKANG PENETAPAN SIMMA BAGI PERTAPAAN PADA MASA PEMERINTAHAN AIRLANGGA (1019-1043 M)}

\author{
BACKGROUND OF THE ESTABLISHMENT OF SIMMA FOR \\ HERMITAGE IN THE REIGN OF AIRLANGGA (1019-1043 C.E.)
}

\begin{abstract}
Abstrak. Penelitian mengenai prasasti-prasasti pada masa pemerintahan Airlangga telah banyak dilakukan. Namun, penelitian mengenai latar belakang kebijakan Airlangga yang berkaitan dengan kehidupan politik, ekonomi, dan sosioreligi kerajaannya dengan berdasar pada bukti prasasti belum banyak disentuh oleh arkeolog maupun ahli epigrafi. Penelitian ini bertujuan untuk mengetahui latar belakang salah satu kebijakan Airlangga berupa penetapan sima bagi pertapaan. Penelitian ini bersifat deskriptif analitis menggunakan pendekatan epigrafi dengan data utama berupa alih aksara dan alih bahasa prasasti, serta data sekunder berupa naskah kesastraan dan literatur mengenai Airlangga dari buku, jurnal, laporan penelitian, skripsi, tesis, dan disertasi. Analisis penelitian dilakukan terhadap isi prasasti dan kebijakan yang dilakukan selama Airlangga menjadi raja. Hasil penelitian menunjukkan bahwa terdapat dua faktor yang melatarbelakangi penetapan simma bagi pertapaan pada masa Airlangga yaitu faktor politik sebagai upaya menarik simpati dan menegakkan hegemoninya sebagai raja dan faktor sosio-religi berkaitan dengan kewajiban raja untuk mengayomi rakyat.
\end{abstract}

Kata kunci: Prasasti, Sīma, Airlangga, Pertapaan

\begin{abstract}
Investigations to the inscriptions of Airlangga have been conducted by many experts. However, the study about the background of policies that had been done by Airlangga from the inscriptions has not been done yet. This article aims to understand the background of one of the Airlangga's policies establish sima for hermitage. This study uses the analytical and descriptive method as transcription and transliteration of inscriptions as main data, also literary text, and literature about the reign of Airlangga from books, journals, etc. The analysis process conducted by identifying the content of the inscriptions and policies which were decided by Airlangga. The result of this study shows there are two factors encourage the establishment of sima for hermitage which are political factor as an effort to get sympathy and spread hegemonies and socio-religious factor which related to the obligation of the king to protect his people.
\end{abstract}

Keywords: Inscriptions, Sīma, Airlangga, Hermitage

\section{PENDAHULUAN}

Prasasti menjadi sumber yang sangat penting bagi penulisan sejarah kuno Indonesia. Prasasti didefinisikan sebagai berbagai tulisan kuno yang dipahatkan pada benda keras, seperti logam, batu, kayu yang bertulis, dan tanah liat yang dibakar, dikeluarkan oleh pejabat kerajaan maupun bukan pejabat, berisi relatif panjang, dan memerlukan interpretasi untuk mendapatkan informasi yang terkandung di dalamnya (Suarbhawa 2000; Dwiyanto 2018). Bakker (1972) berpendapat, bahwa prasasti merupakan sumber sejarah dengan tingkat keabsahan tertinggi karena dibuat sezaman dengan peristiwa yang diceritakan di dalamnya (otentik). Prasasti juga dikatakan sebagai tulang punggung penulisan sejarah kuno Indonesia karena dapat mengungkapkan berbagai aspek kehidupan masa lampau, seperti agama, politik, ekonomi, adat istiadat, hukum, sosial, dan lainnya (Yulianto 1996b).

Prasasti yang ditemukan di Indonesia, khususnya Jawa, sebagian besar berisi tentang penetapan hak istimewa atas tanah yang disebut sima (Boechari 2012a). Sima berasal dari bahasa Sanskerta "sima" yang berarti batas dan diserap dalam bahasa Jawa Kuno menjadi "sīma" yang artinya tanah atau desa yang dibebaskan dari pajak dan kewajiban lainnya (Zoetmulder dan Robson 1995). Menurut Riboet Darmosoetopo (2003), sima dapat diartikan sebagai sebidang tanah yang diberi batas dan dibebaskan dari pajak dan sejumlah 
kewajiban oleh raja atau pejabat tinggi. Penetapan sima pada masa Jawa Kuno merupakan peristiwa sakral karena berkaitan dengan perubahan status tanah dan mekanisme pengelolaan suatu lahan.

Prasasti tentang sima pada masa Jawa Kuno ditemukan dari abad ke-8 sampai $15 \mathrm{M}$. Salah satu masa dengan bukti tinggalan tertulis prasasti yang melimpah dan signifikan adalah masa pemerintahan Airlangga. Airlangga adalah seorang raja yang memerintah kerajaan Mataram Kuno pada tahun 1019 sampai 1043 M, setelah raja Dharmawangśa Tguh (Poesponegoro dan Notosusanto 2008). Selama menjadi raja, Airlangga mengeluarkan 33 prasasti yang semuanya berisi mengenai pemberian anugerah raja berupa penetapan sebidang tanah menjadi sima untuk seseorang, kelompok, atau penduduk karena alasan tertentu (Susanti 2010).

Alasan penetapan sima pada prasastiprasasti masa Airlangga beragam, mulai dari pemberian anugerah atas seseorang yang berjasa bagi raja, misalnya Prasasti Terep I dan II (954 Ś/1032 M), penetapan sima bagi penduduk desa yang berjasa menolong raja saat perang misalnya, Prasasti Cane (943 S/1021 M) dan Prasasti Baru (952 Ś/1030 M), untuk pemeliharaan infrastruktur kerajaan seperti Bendungan Waringin Sapta dalam Prasasti Kamalagyan (959 Ś/1037 M), dan yang untuk pemeliharaan bangunan keagamaan misalnya, pada Prasasti Turunhyang A (958 Ś/1036 M) dan Prasasti Pucangan bahasa Jawa Kuno ${ }^{1}$ (963 Ś/1041 M) (Susanti 2010). Prasastiprasasti tersebut menyiratkan adanya usaha raja dalam mengembangkan aspek politik, sosial, ekonomi, dan religi kerajaan.

Satu hal menarik dari prasasti-prasasti yang dikeluarkan Airlangga, yaitu adanya perhatian akan bangunan keagamaan berupa pertapaan. Pertapaan dalam bahasa Jawa Kuno disebut patapān, parapatapan atau partapān, dan diartikan sebagai tempat kediaman para pertapa atau tempat untuk bertapa (Zoetmulder dan Robson 1995). Perhatian akan pertapaan pada masa Airlangga dapat dilihat dari pembangunan dan penetapan sima bagi pertapaan yang disebutkan dalam Prasasti Terep I dan II (954 Ś/1032 M),

\footnotetext{
1 Penambahan kata "bahasa" pada nama prasasti dimaksudkan untuk membedakan antara Prasasti Pucangan berbahasa Jawa 2
}

Prasasti Turunhyang A (958 Ś/1036 M) dan Prasasti Pucangan bahasa Jawa Kuno (963 Ś/1041 M). Dilihat dari konteks masa pemerintahan Airlangga, perhatian akan bangunan keagamaan, khususnya pertapaan, terkait dengan kebijakan Airlangga sebagai raja dalam membina aspek religi kerajaan.

Bangunan keagamaan merupakan salah satu sarana prasarana penting pada masa Jawa Kuno. Sarana ini digunakan sebagai tempat melakukan ritual keagamaan, tidak terkecuali pertapaan sebagai bangunan keagamaan kaum $r_{s ̦ i}$ dan pertapa. Penetapan sima bagi bangunan keagamaan terkait dengan aspek religi dan kebutuhan bangunan keagamaan itu sendiri. Jika dihubungkan dengan alasan turunnya anugerah raja dan kondisi kerajaan, upaya penetapan sima dalam prasasti-prasasti yang dikeluarkan Airlangga juga dapat dilihat dari kacamata politik sebagai langkah legitimasi raja. Selain itu, dapat dilihat juga adanya kebebasan beragama saat itu, seperti dalam Prasasti Baru (952 Ś/1030 M) yang menyebutkan agama rși pertama kali dan posisinya sejajar dengan agama Siwa dan Buddha (Susanti 2010).

Oleh karena itu, penelitian ini berupaya untuk mengkaji latar belakang penetapan sima bagi pertapaan pada masa Airlangga (1019-1048 M). Penelitian ini berusaha untuk menjelaskan salah satu kebijakan Airlangga sebagai raja mengenai bangunan keagamaan. Selama ini, penelitian mengenai prasasti-prasasti masa Airlangga sudah banyak dilakukan. Namun, belum pernah ada penelitian yang membahas secara spesifik mengenai latar belakang kebijakan yang dikeluarkan Airlangga untuk mengembangkan kerajaannya.

Menurut Riboet Darmosoetopo (2003), pemberian anugerah raja berupa penetapan sima berkaitan dengan hak dan kewajiban raja untuk menjamin kesejahteraan dan kebahagiaan rakyat. Raja berhak menghukum dan memberi hadiah (wnan் wigrahānugraha). Pemberian anugerah tersebut tidak dilakukan secara sembarangan, artinya dilandasi oleh alasan-alasan tertentu.

Berdasarkan uraian di atas, permasalahan dalam penelitian ini adalah apa latar belakang penetapan sima bagi pertapaan pada masa Airlangga. Penulisan artikel ini bertujuan untuk

Kuno berangka tahun 963 Ś/1041 M dan Prasasti Pucangan berbahasa Sanskerta berangka tahun 959 Ś/1037 M. 
menjelaskan kondisi kerajaan Mataram Kuno masa Airlangga dan kebijakan yang dibuatnya sebagai raja untuk mengetahui faktor yang melatarbelakangi penetapan sīma bagi pertapaan pada masa itu. Selain itu, melalui artikel ini diharapkan dapat memberikan gambaran yang lebih lengkap mengenai kehidupan Kerajaan Mataram Kuno masa Airlangga, khususnya dalam hal latar belakang kebijakan yang dikeluarkan Airlangga dan gambaran pertapaan sebagai salah satu bangunan keagamaan yang penting pada masa Jawa Kuno.

\section{METODE}

Penelitian ini bersifat deskriptif analitis dengan menggunakan pendekatan epigrafi. Penelitian terdiri dari beberapa tahapan, yaitu pengumpulan data, analisis data, interpetasi, dan penarikan kesimpulan. Tahap pertama adalah pengumpulan data yang berupa alih aksara dan alih bahasa prasasti-prasasti masa Airlangga melalui katalog prasasti dan literatur lainnya. Tiga prasasti dipilih sebagai data dari total 33 prasasti yang dikeluarkan Airlangga. Prasasti yang dipilih adalah prasasti yang mengandung kata patapān dan/atau dharmma karsyan serta berisi mengenai penetapan sima bagi pertapaan. Prasasti-prasasti tersebut adalah Prasasti Terep I dan II (954 Ś/1032 $M)$ yang menyebutkan pemberian status sima bagi patapān i Tṛp (Christie 1999; Wurjantoro 2018), Prasasti Turunhyang A (958 Ś/1036 M) yang menyebutkan pembangunan pertapaan bernama Śrī Wijayaṡrama (Brandes 1913; Christie 1999), dan Prasasti Pucangan bahasa Jawa Kuno (963 Ś/1041 M) yang menyebutkan penetapan Desa Barahem, Pucangan, dan Sapuri sebagai sima untuk mendirikan dharmma karsyan bagi para rși (Yulianto 1996a). Selain prasasti, digunakan juga sumber lain berupa naskah kesastraan dan literatur yang memuat mengenai kehidupan Airlangga maupun bagian yang menyinggung mengenai pertapaan dan kehidupan pertapa.

Tahap kedua adalah analisis data yang meliputi bagian penanggalan, alasan penetapan (sambandha), penerima anugerah serta tanah yang dijadikan sima untuk mengetahui latar belakang penetapannya. Analisis mengenai kehidupan kerajaan dan kebijakan Airlangga selama menjadi raja juga dilakukan berdasarkan prasasti-prasasti Airlangga. Ketiga, tahap interpretasi yang dilakukan dengan mengintegrasikan hasil analisis yang didapatkan untuk diberikan makna serta penjelasan mengenai faktor-faktor yang melatarbelakangi penetapan sima bagi pertapaan pada masa Airlangga. Terakhir, dilakukan penarikan kesimpulan dari hasil interpretasi yang didapat, sehingga dapat menjawab permasalahan penelitian berupa latar belakang penetapan sima bagi pertapaan pada masa Airlangga.

\section{HASIL DAN PEMBAHASAN}

\section{Kondisi Kerajaan Mataram Kuno Masa Pemerintahan Airlangga (1019-1043 M)}

Airlangga adalah raja yang memerintah kerajaan Mataram Kuno selama kurang lebih 25 tahun. Selama masa pemerintahannya, banyak dikeluarkan prasasti-prasasti yang dapat menjelaskan kondisi kehidupan kerajaan dan masyarakat di kerajaannya meliputi kondisi politik, kondisi ekonomi, dan kondisi sosio-religi.

\section{Kondisi politik kerajaan}

Pemerintahan Mataram Kuno sebelum Airlangga dipegang oleh raja Dharmawangśa Tguh Anantawikrama, yang menurut naskah Wirataparwwa, naskah yang disadur dari bahasa Sanskerta pada sekitar tahun 918 Ś (996 M), memiliki nama Abhiseka Śrī Iśāna Dharmawangśā Tguh Anantawikramottunggadewa dan memerintah pada akhir abad ke-10 M sampai awal abad ke-11 M (Susanti 2010; Nasoichah 2017). Prasasti Pucangan berbahasa Sanskerta (959 Śl1037 M) menginformasikan terjadinya serangan dari seorang tokoh bernama Haji Wurawari pada $1016 \mathrm{M}$ saat pesta pernikahan putri Dharmawangśa Tguh dengan Airlangga, sehingga menyebabkan kehancuran kerajaan tersebut.

Airlangga memiliki nama lahir (garbhanāma) Dharmawangśa Airlangga. Berdasarkan silsilahnya, Airlangga merupakan anak dari Gunapriyadharmapatnī atau Mahendradattā, keturunan langsung Mpu Sindok dari Śrī Makutawangśawardhana, dengan putra mahkota Wangsa Warmadewa dari Bali bernama Dharmodāyana (Julianto 2012). Setelah 
kehancuran kerajaan karena peristiwa yang dalam Prasasti Pucangan berbahasa Sanskerta disebut pralaya², Airlangga dan Narottama, abdinya yang setia, melarikan diri ke hutan dan menjadi seorang pertapa sembari mengumpulkan kekuatan untuk merebut kembali tahtanya (Susanti 2010). Menurut Ninie Susanti (2010), berdasarkan prasastiprasastinya, masa pemerintahan Airlangga dapat dibagi menjadi 3 fase yaitu, fase konsolidasi (1019$1037 \mathrm{M})$, fase keemasan (1037-1042 M), dan masa akhir pemerintahan (1042-1043 M).

Fase konsolidasi adalah masa setelah pralaya saat Airlangga melakukan upaya-upaya penegakan hegemoninya sebagai raja. Berdasarkan Prasasti Pucangan berbahasa Sanskerta (959 Śl1037 M), setelah pengasingannya di hutan, Airlangga dinobatkan menjadi raja oleh pendeta Siwa, Buddha, dan Mahabrāhmana pada tahun 941 Ś (1019 M) dengan gelar Rake Halu Śrī Lokeśwara Dharmawangśa Airlangga Anantawikramottunggadewa (Poesponegoro dan Notosusanto 2008). Gelar penobatan Airlangga merupakan salah satu bagian dari upaya legitimasi sebagai raja baru dengan menganggap dirinya sebagai seorang raja, seorang tokoh titisan dewa tertinggi penguasa dunia yang gagah berani dan tidak dapat dibinasakan (Susanti 2010). Selama fase konsolidasi, Airlangga berupaya menyatukan kembali kerajaannya dengan cara memerangi musuh-musuhnya. Prasasti Cane (943 Ś/1021 M) memberitakan kemenangan raja mengalahkan musuhnya yang berasal dari wilayah barat. Tahuntahun berikutnya, menurut Prasasti Pucangan berbahasa Jawa Kuno, yaitu pada 951 Ś (1029) terjadi penyerangan ke Wuratan tempat raja Wisnuprabha (Susanti 2010). Berdasarkan Prasasti Baru 952 Ś (1030 M), raja Airlangga memperoleh kemenangan dari raja Hasin sehingga menetapkan Desa Baru sebagai sima. Pada tahun 953 Ś (1031 M) Airlangga mengalahkan Haji Wěngkěr, Panuda, yang sempat melarikan diri ke Desa Galuh dan Barat dan pada tahun 954 Ś (1032 M) dilakukan penyerangan ke keraton Haji Wurawari dari Magehan. Namun, Prasasti Terep
(954 Ś/1032 M) memberitakan bahwa Airlangga juga mengalami kekalahan sehingga harus meninggalkan keratonnya di Wwatan Mas ke Patakan (Susanti 2010).

Prasasti Turunhyang A (958 Ś/1035 M) memberitakan tidak ada lagi musuh kerajaan sehingga Airlangga memberi anugerah sima kepada Desa Turunhyang bagi pembangunan pertapaan bernama Śrī Wijayaśrama. Akan tetapi, pada tahun 957 Ś (1035 M) terjadi penyerangan lagi ke Haji Wěngkěr bernama Wijayawarmma di Tapa, namun baru tertangkap oleh tentara Airlangga pada tahun 959 Ś (3 November 1037 M) (Poesponegoro dan Notosusanto 2008). Setelah penyerangan terakhir itu, dikatakan bahwa kerajaan telah berada pada masa damai, yang pada Prasasti Pucangan berbahasa Sanskerta (959 Ś/1037 M) dikatakan "maka ia pun duduk di atas singgasana dan meletakkan kakinya di atas kepala musuhmusuhnya", serta dilakukan pembangunan pertapaan di Gunung Pugawat sebagai tanda janji raja (Susanti 2010).

Setelah musuh-musuh Airlangga berhasil dikalahkan, dimulailah fase keemasan dari tahun 1037-1042 M. Fase ini Airlangga lebih fokus untuk membangun kerajaannya dan memakmurkan rakyatnya baik dalam bidang ekonomi, sosial, maupun religi. Hal tersebut dilakukan dengan cara memperbaiki pengairan, memperbaiki sarana prasarana transportasi darat maupun air, mengembangkan perdagangan lokal maupun internasional, mendukung kegiatan religi dengan cara memberikan anugerah sima bagi pembangunan dan pemeliharaan bangunan keagamaan, dan terakhir meraih simpati dan dukungan dari rakyatnya (Susanti 2010).

Salah satu upaya Airlangga memajukan kerajaan terekam dalam Prasasti Kamalagyan (959 Ś/1037 M) yang menceritakan peringatan pembangunan Bendungan Waringin Sapta dan penetapan Desa Kamalagyan sebagai sima untuk memelihara bendungan tersebut (Yulianto 1996a). Pembangunan bendungan dimaksudkan untuk mencegah banjir Sungai Brantas yang menggenangi perkampungan penduduk, sawah, kebun, bangunan

\footnotetext{
2 Diartikan sebagai penghancuran, pembinasaan, kematian, bencana, atau dapat juga diartikan kiamat yang terjadi pada akhir zaman Kalpa (Zoetmulder dan Robson 1995). 4
} 
suci, dan pertapaan. Selain itu, Bendungan Waringin Sapta juga merupakan salah satu fasilitas transportasi air bagi perdagangan lokal dan internasional melalui Pelabuhan Hujung Galuh sebagai pelabuhan utama yang menghubungkan Jawa dengan pulau-pulau lain di Nusantara (de Casparis 1958). Dalam mendukung kehidupan religi, Airlangga membangun bangunan keagamaan, misalnya diceritakan dalam Prasasti Pucangan berbahasa Jawa Kuno (963 Ś/1041 M) membangun dharmma karsyan sebagai tempat ibadah para rși, serta dalam Prasasti Turunhyang A (958 Ś/1035 M) membangun pertapaan yang bernama Śrī Wijayaśrama (Susanti 2010). Terakhir, untuk mendapat dan mempertahankan simpati rakyat, Airlangga memberikan anugerah sima kepada penduduk desa yang berjasa, misalnya Desa Pandan yang diceritakan dalam Prasasti Pandan (964 Ś/1042 M) berjasa membantu raja mengalahkan musuhnya (Nugroho 2015).

Masa akhir pemerintahan Airlangga ditandai oleh Prasasti Gandhakuti (964 Ś/1042 M) dengan mundurnya Airlangga dari kerajaan dan menjadi seorang pendeta bergelar Aji Pāduka Mpungku Sang Pinakachattraning Bhuwana (Susanti 2010). Akan tetapi, terjadi kerusuhan di kerajaannya karena penerus Airlangga yang seharusnya menjadi raja yaitu Rakryān Mahāmantri i Hino Śrī Sanggrāmawijaya Dharmaprasādottunggadewi melepaskan tahtanya. Oleh karena hal tersebut, Airlangga kembali menduduki tahtanya, dibuktikan dengan dikeluarkannya Prasasti Pamwatan yang menyebutkan gelar penobatannya sebagai raja (abhișekanāma). Selain itu, dikeluarkan juga Prasasti Pasar Legi yang berangka tahun 965 Ś (1043 M) sebagai prasasti terakhir yang dikeluarkan Airlangga sebagai raja (Susanti 2010; Boechari 2012b). Pada akhir pemerintahannya, Airlangga membagi kerajaannya menjadi dua yang dibuktikan dengan keterangan dari Prasasti Wurare (1211 Ś/1289 M) dan Naskah Calon Arang yang menjelaskan bahwa Airlangga menempatkan Samarawijaya sebagai raja Panjalu dan Mapañji Garasakan sebagai raja Janggala. Kedua kerajaan tersebut kemudian saling berperang satu sama lain untuk memperebutkan wilayah, seperti yang diceritakan dalam Prasasti Turunhyang B (966 Ś/1044 M), Prasasti Malenga (974 Ś/1052 M),
Prasasti Banjaran (974 Ś/1052 M), dan Prasasti Garaman (975 Ś/1053 M) (Boechari 2012c).

Mengenai struktur birokrasi kerajaan, Ninie Susanti (2010) berpendapat bahwa struktur birokrasi masa pemerintahan Airlangga, dilihat dari prasastiprasastinya, mengalami penyederhanaan karena tidak disebutkannya secara rinci pejabat-pejabat di tingkat pusat, daerah, maupun desa. Pada bagian awal prasasti yang menjelaskan pemberi dan penerima perintah, raja merupakan pihak yang memberi perintah kepada pejabat bernama Rakṛyān Mahāmantri i Hino Śrī Sanggrāmawijaya Dharmaprasādottunggadewi. Jabatan ini sangat dekat dengan raja dan ditempati oleh putra mahkota yang merupakan putra putri raja (Boechari 2012b). Pada prasasti Terep I dan II (954 Ś/1032 M), perintah raja juga diterima oleh Rakryān Kanuruhun Mpu Dharmmamūrtti Narottama Dānasūra di mana jabatan tersebut dalam Prasasti Baru (952 Ś/1030 M) juga sebagai pelaksana perintah raja. Prasasti Cane (943 Ś/1021 M) menyebutkan pejabat pelaksana perintah raja yang lain, yaitu Rakai Paḍang Pu Jiwa dan Rakryan Jasun Mapapan. Prasasti Baru (952 Ś/1030 M) menyebutkan Rakryan Hujun Pu Amrta, dan Prasasti Kakurugan (945 Ś/1023 M) serta Prasasti Munggut (944 Ś/1022 M) menyebutkan Tanḍa Rakryān ring Pakirakiran yang mana pada masa Majapahit jabatan tersebut adalah jabatan tinggi utama yang di dalamnya terdiri dari rakryān mapatih, rakryān dmung, rakryān kanuruhun, rakryān rangga, dan rakryān tuměnggung (Boechari 2012b). Terdapat juga kelompok mangilala drawya haji yang tinggal di dalam keraton (wargga $i$ jro) dan terdiri dari petugas administrasi pemungut pajak kerajaan, pengusaha dan pengrajin yang digaji raja, serta petugas yang melayani kebutuhan keraton dan diupah raja. Pada masa Airlangga, kelompok ini berjumlah 169 petugas (Sedyawati 1985; Susanti 2010).

\section{Kondisi ekonomi kerajaan}

Masa pemerintahan Airlangga memiliki beberapa sektor. Sektor agraris, meliputi pertanian dan perkebunan memegang peran penting bagi kerajaan. Hal ini didukung oleh kondisi geografis Jawa Timur yang memiliki wilayah alluvial dari sungai-sungai besar, seperti Brantas dan Bengawan Solo yang luas, dan cocok untuk pertanian dan 
perkebunan (de Casparis 1958). Prasasti-prasasti yang dikeluarkan Airlangga menyebutkan penggunaan lahan yang beragam, berkaitan dengan pertanian, yaitu sawah, kebun, ladang, dan tanah pertanian. Berdasarkan Prasasti Terep I dan II (954 Ś/1032 M), sebagai penunjang pertapaan (patapān i trp), tiga sawah yang ada di utara, timur, dan sawah di Wuntalan seluas 1 tampah ditetapkan menjadi sima. Begitupun Prasasti Turunhyang A (958 Ś/1035 M) yang menjelaskan bahwa hasil dari sawah yang ditetapkan sebagai sīma dibayarkan sebesar emas 2 sūwarna setiap bulan Asuji untuk biaya pemujaan. Prasasti Kamalagyan (959 Ś/1037 M) juga menyebutkan sawah seluas 6 tampah yang hasilnya dibayarkan sebesar emas 6 sūwarña, 7 māsa, 4 kupang (Siswanto 2018). Sawah-sawah tersebut walaupun penghasilannya tidak masuk ke kas kerajaan, tetapi digunakan sebagai dana penunjang pemeliharaan bangunan keagamaan dan fasilitas kerajaan.

Upaya untuk mendukung usaha pertanian dan perkebunan pada masyarakat Jawa Kuno salah satunya adalah dengan membangun saluran irigasi, seperti yang dilakukan Airlangga sebagaimana dijelaskan dalam Prasasti Kamalagyan (959 S/1037 M). Bendungan memiliki manfaat, selain menjadi fasilitas irigasi, juga mencegah banjir, tempat budidaya ikan, dan mengatur lalu lintas perdagangan. Selain bendungan (dawuhan), dikenal juga istilah tambak dan mula yang merupakan fasilitas irigasi pertanian (Darmosoetopo 2003). Terdapat juga struktur pejabat desa yang berhubungan dengan pertanian, sebagai usaha untuk menjaga usaha dan hasil pertanian, misalnya hulair atau huler yang bertanggungjawab mengawasi irigasi dan pembagian air untuk pertanian, matamwak yang bertanggungjawab mengurusi bendungan, hulu wras dan wahuta maweas yang mengurusi beras dan padi (Susanti 2010).

Selain pertanian, perdagangan juga menjadi sektor penting ekonomi kerajaan. Dalam prasasti dijumpai istilah masamwyawahāra yang diartikan sebagai kegiatan berdagang. Perdagangan pada masa itu dilakukan dengan berpindah dari satu pasar (pěkěn) ke pasar lainnya sesuai dengan hari pasaran yang bersiklus 5 harian (pañcawāra).
Barang dagangan yang diperjualbelikan bermacammacam, seperti sandang, pangan, ternak, saji-sajian dan alat-alat rumah tangga (Darmosoetopo 2003). Prasasti juga menyebutkan usaha pembatasan pajak dengan cara membatasi jenis pedagang dan jumlah barang dangangan tertentu, misalnya dalam Prasasti Cane (943 Ś/1021 M) disebutkan penjualan kerbau dibatasi 20 ekor, sapi atau kerbau dibatasi 40 ekor, kambing dibatasi 80 ekor, bebek sebatas sekandang, pandai besi yang menggunakan tiga landasan dan sepasang alat pemutar, serta tukang kayu dan pembuat keris masing-masing satu pemimpin (tuhan) (Susanti 2010).

Perdagangan internasional juga mengambil tempat penting dalam ekonomi kerajaan. Prasasti Kamalagyan (959 Ś/1037 M) (Gambar 1) bercerita mengenai pembangunan Bendungan Waringin Sapta dan dari prasasti tersebut dapat diketahui adanya Pelabuhan Hujung Galuh sebagai pelabuhan internasional yang ramai saat itu. Berkembangnya perdagangan emporia saat itu menjadikan Jawa, khususnya Jawa Timur, sebagai wilayah yang ramai dikunjungi pedagang asing. Perdagangan emporia merupakan sistem perdagangan dari satu pelabuhan ke pelabuhan lain atas persetujuan politik (Susanti 2010). Bukti perdagangan internasional ini yaitu dalam Prasasti Kamalagyan disebutkan profesi nahkoda dan pedagang antarpulau. Adapun dalam Prasasti Kamalagyan (959 Ś/1037 M) baris 12, dijelaskan sebagai berikut:

"...kapwa ta sukhamanah nikāng maparahu samanhulu mangalap bhānda ri hujung galuh tka rikāng parapuhawang para banyāga sangkāring dwīpantara samañantěn ri hujung galuh..."

Artinya: "semuanya bergembira, pemilik kapal dari hulu yang mengantar barangnya ke Hujung Galuh, dan juga kapten kapal dan pedagang dari pulau lainnya, mereka semua berkumpul di Hujung Galuh" (Jones 1984; Yulianto 1996a).

Jawa memiliki peran yang signifikan dalam perdagangan emporia sebagai wilayah pusat pertukaran dan distribusi komoditas impor dan ekspor yang beragam, seperti hasil alam berupa pangan, hasil hutan berupa cula badak, tempurung kura-kura, dan bulu burung, hasil kerajinan, serta barang-barang mewah seperti perhiasan (Setyawatiningrum 2016). 


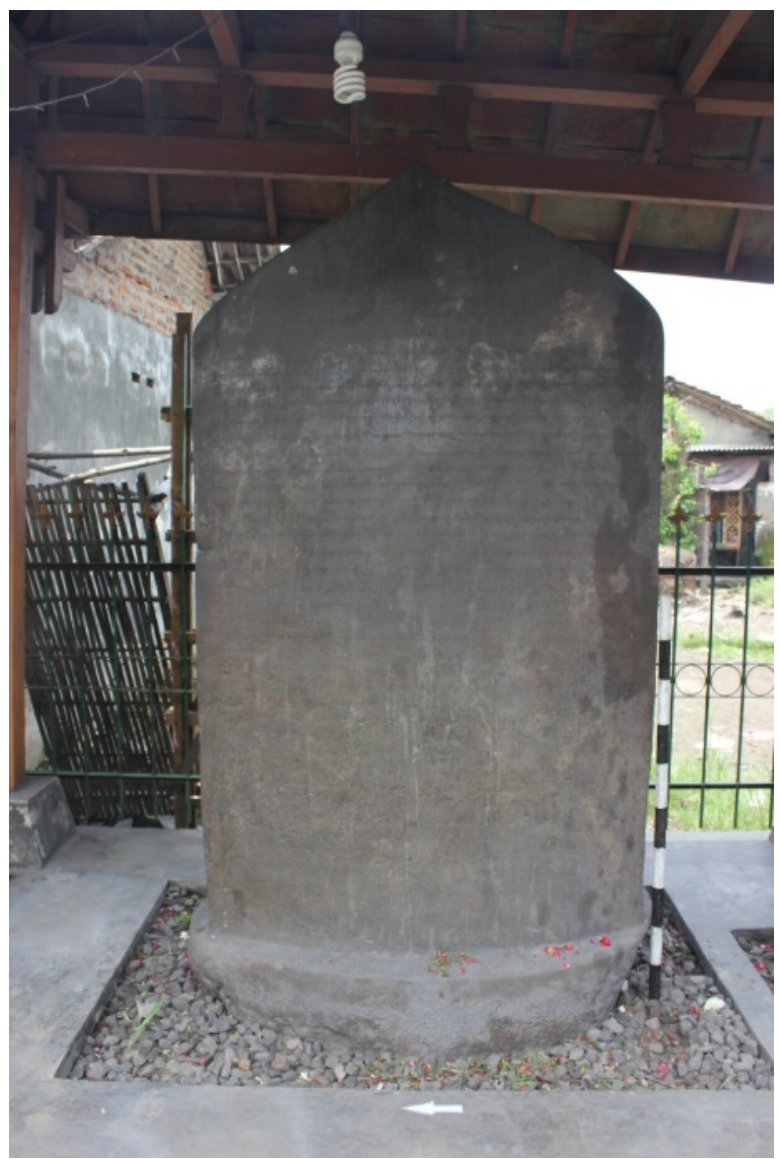

Sumber: cagarbudaya.kemdikbud.go.id

Gambar 1 Prasasti Kamalagyan di dusun Kelagen, Desa Tropodo, Kecamatan Krian, Sidoarjo

Keberadaan orang asing yang disebut sebagai wargga kilalān juga menjadi bukti perdagangan internasional di Jawa masa itu. Selain itu, pembangunan sarana prasarana perdagangan seperti bendungan dan penetapan sima untuk menjaga bendungan tersebut menjadi bukti keseriusan raja dalam mengembangkan perdagangan sebagai salah satu sektor ekonomi utama kerajaan. Menurut Kenneth R. Hall (2011), keberhasilan mengembangkan perdagangan pada masa Jawa Timur abad ke-10-11 M disebabkan karena wilayah Jawa Timur memiliki akses yang lebih baik ke wilayah pesisir, kondisi Sungai Brantas dan Bengawan Solo yang lebih dapat dilayari dan dilalui kapal, serta dukungan penguasa berupa pembangunan fasilitas perdagangan dan pengaturan manajemen irigasi yang baik.

\section{Kondisi sosio-religi kerajaan}

Masyarakat Jawa Kuno, khususnya masa pemerintahan Airlangga, mengenal adanya stratifikasi sosial. Seperti tersirat dalam prasasti dan naskah kesastraan, kedudukan suatu golongan dijelaskan selalu diikuti oleh hak dan kewajiban, serta peranannya dalam masyarakat. Golongan tertinggi dalam masyarakat ditempati oleh raja sebagai penguasa kerajaan. Raja dianggap sebagai poros kerajaan yang mendapatkan kewibawaannya melalui kultus dewa raja dan pelaksanaan ritual tertentu untuk mendapatkan prestise dan menjaga keserasian kerajaan (Lombard 2018). Airlangga menganggap dirinya sebagai titisan Avalokiteśwara, Buddha penguasa dunia, dilihat dari nama penobatannya sebagai raja yang mengandung nama Śrī Lokeśwara sebagai nama lain dari Buddha Avalokiteśwara (Susanti 2010). Selain itu, Airlangga juga dianggap titisan Dewa Wisnu, dewa pemelihara dunia, yang diwujudkan melalui penggunaan lambang kerajaan Garuḍhamukha pada prasastiprasastinya sebagai simbol kendaraan Dewa Wisnu dan simbol dari jiwa pemberani dan pembasmi musuh (Witasari 2011). Golongan kedua terdiri dari keluarga raja dan kaum bangsawan yang menduduki jabatan tinggi tertentu. Di bawahnya, terdapat pegawai kerajaan yang terdiri dari pegawai pusat yang berkedudukan di ibukota dan pejabatpejabat daerah. Selanjutnya yaitu kaum agamawan yang memiliki pengaruh kuat juga di kerajaan, serta yang terendah dalam adalah masyarakat biasa yaitu penduduk desa (Susanti 2010).

Stratifikasi sosial yang telah disebutkan di atas tidak bersifat tertutup, dalam artian golongan masyarakat kelas bawah tidak menutup kemungkinan dapat menduduki golongan masyarakat kelas atas karena suatu hal, begitupun sebaliknya. Kasus mobilitas vertikal naik pada masa Airlangga terjadi kepada Narottama dan Rake Pangkaja Dyah Tumambong. Narottama, dalam Prasasti Pucangan berbahasa Sanskerta (959 Ś/1037 M), dikatakan sebagai abdi Airlangga yang setia saat mengasingkan diri ke hutan dan selalu mengikuti apa yang Airlangga lakukan ketika menjadi pertapa. Prasasti Baru (952 Ś/1030 M) menyebutkan gelar yang disandang Narottama yaitu Rakryān Kanuruhun Mpu Dharmmamūrtti Narottama Dānasūra sebagai penerima perintah raja dan pada Prasasti Turunhyang A (958 Ś/1036 M) sebagai pelaksana perintah raja, di mana jabatan ini merupakan jabatan tinggi utama kerajaan dilihat dari perannya sebagai penerima langsung perintah raja dan pemegang lungguh wilayah Kanuruhun (Susanti 
2010). Selain itu, kenaikan stratifikasi sosial juga dialami oleh Rake Pangkaja Dyah Tumambong. Prasasti Terep I dan II (954 Ś/1032 M) menceritakan penetapan sima bagi pertapaan di Terep, Desa Kambang Sri wilayah Pangkaja karena pengabdian luar biasa Rake Pangkaja Dyah Tumambong kepada raja ketika berperang. Dia berdoa tanpa henti kepada arca bhatārī sehingga raja memperoleh kemenangan. Oleh karena itu, raja memberikannya gelar halu, sehingga menjadi Rake Halu Dyah Tumambong dan menganggapnya seolah-olah adik raja (sāksāt anuja śrī mahārāja) (Wurjantoro 2018).

Pemberian anugerah berupa sima menjadi salah satu upaya raja Airlangga untuk menaikkan status seseorang atau kelompok. Hal ini dilakukan karena penetapan simma merupakan anugerah raja yang dipandang penting, peristiwa yang sakral, dan kepala sima mendapatkan hak-hak istimewa tertentu (Darmosoetopo 2003). Prasasti Kakurugan I (945 Ś/1023 M) menceritakan penganugerahan sima Desa Kakurugan kepada Dyaḥ Kakīngadulěngěn dan keturunannya karena kebaktiannya kepada raja, disertai dengan pemberian hak-hak istimewa (Boechari 1985/1986).

Seseorang yang dianugerahi sima disebut sebagai kepala sima dan berhak atas beberapa hal yaitu, berhak melarang kelompok mangilala drawya haji masuk ke wilayah sima-nya dan menarik pajak di wilayah sima-nya, berhak menentukan besarnya denda bila di wilayah simanya terjadi pelanggaran hukum atau dikenal dengan sukhaduhka, dan mendapatkan hak istimewa. Prasasti Baru (952 Ś/1030 M) menyebutkan hak istimewa penerima sima di antaranya adalah boleh memiliki budak berupa dayang, huñjman, nambi, jěnggi, pujut, dan semua jenisnya (wnanaanya mahuluna dayang, huñjman, nambi, pujut, jěnggi, asin salwiranya) (Yulianto 1996a). Selain itu, pada Prasasti Kakurugan (945 Ś/1043 M) juga disebutkan hak istimewa bagi Dyah Kakīngadulěngěn dan keturunannya sebagai kepala sima, seperti boleh memakai kain motif tiang (anapihana saka), memakai karpet selain warna hitam, memakai bedak, memakai perhiasan telinga berbentuk teratai terbelah (tan jamūs añjwa halan asumpinatunjun siniwak), memakan hidangan khusus raja, seperti kura-kura, kambing muda kendit, anjing yang dikebiri, babi hutan aduan, babi hutan yang mati digantung (wnanamanana salwirnin rājaman்śa badawan wộs guntin, asu tugěl, karuñ puliḥ, matī ngantunan), boleh memiliki pendopo (waruga tinuwun), dan luput dari amukan (añluputānāmuk) (Susanti 2010).

Komposisi masyarakat masa Airlangga juga menjadi hal yang menarik. Komposisi masyarakat pada masa itu tidak hanya masyarakat asli atau pribumi, tapi juga terdapat orang asing yang disebut sebagai wargga kilalān yang berprofesi sebagai pedagang. Orang asing dalam prasasti terdiri dari Klin (Keling, India), Aryya (India), Sinhala (Srilanka), Pandikira (Asia Selatan), Drawida (India), Campa (Vietnam), Kmir (Khmer) dan Rěměn (Mon). Mereka disebut sebagai kelompok yang dikenai pajak dalam prasasti dan menyiratkan kelompok tersebut dalam jumlah yang besar (Jones 1984; Susanti 2010).

Selain aspek sosial, aspek religi juga menarik untuk dibahas. Masyarakat Jawa Kuno menganggap agama sebagai aspek kehidupan yang sangat penting. Bukti-bukti arkeologis yang telah terungkap sampai saat ini, bahkan mayoritas berhubungan dengan aspek religi masyarakat Jawa Kuno. Kehidupan religi masyarakat pada masa Airlangga juga dijelaskan dari prasasti-prasasti yang dikeluarkannya dan didukung oleh bukti arkeologis lainnya. Berdasarkan keterangan dari prasastiprasastinya, diketahui ada empat agama yang berkembang saat itu, yaitu Hindu, Buddha, Rși dan Brahmana seperti yang dikutip dalam Prasasti Baru (952 Ś/1030 M) baris ketujuh sebagai berikut:

"... siddha manoratha pwa paduka śrī mahārāja

kanuruhun mpungku śaiwa sogata rși...".

Artinya: "setelah itu bersenang-senanglah Paduka Sri Maharaja disaksikan oleh para pendeta Siwa, Buddha dan Rși" (Yulianto 1996a).

Selain itu, Prasasti Pucangan berbahasa Jawa Kuno (963 Ś/1041 M) baris ke-15 juga menyebutkan sebagai berikut:

“...sanajña kāstwan śrī mahārāja de mpungku sogata maheswara mahābrahmana..."

Artinya: "penobatan Sri Maharaja direstui oleh para pendeta Buddha, Maheswara (Siwa) dan Mahabrahmana" (Susanti 2010).

Agama Hindu aliran Waisnawa tergambar dari kultus Airlangga sebagai titisan Wisnu di mana 
lambang kerajaan memakai simbol Garuḍhamukha (Gambar 2) yang merupakan hewan kendaraan (wāhana) Dewa Wisnu. Berdasarkan Prasasti Pucangan berbahasa Sanskerta (954 Ś/1032 M), Airlangga disamakan dengan sthanu yang merupakan nama lain Dewa Wisnu dan pada Prasasti Pucangan bahasa Jawa Kuno (963 Ś/1041 M) juga menyebut Airlangga sebagai jelmaan dari Wisnumurtti (Dewa Wisnu) yang tidak dapat dihancurkan oleh mahapralaya (Susanti 2010).

Satu hal yang menarik, pada masa Airlangga agama rși untuk pertama kalinya disebut dalam prasasti dan dari prasasti-prasastinya juga terdapat dukungan raja terhadap penganut agama ini. Menurut Hariani Santiko (1990), rși adalah golongan agamawan yang tinggi pengetahuannya dan hidup di tempat yang sunyi seperti hutan. Golongan agama ini menjalankan ibadah dan kegiatannya di pertapaan dan dharmma karsyan. Pada masa Airlangga, dilakukan pembangunan dan penetapan sima untuk pertapaan dan dharmma karsyan seperti yang terdapat dalam Prasasti Pucangan berbahasa Jawa Kuno (963 Ś/1041 M), Prasasti Terep I dan II (954 Ś/1032 M), dan Prasasti Turunhyang A (958 Ś/1036 M) (Susanti 2010).

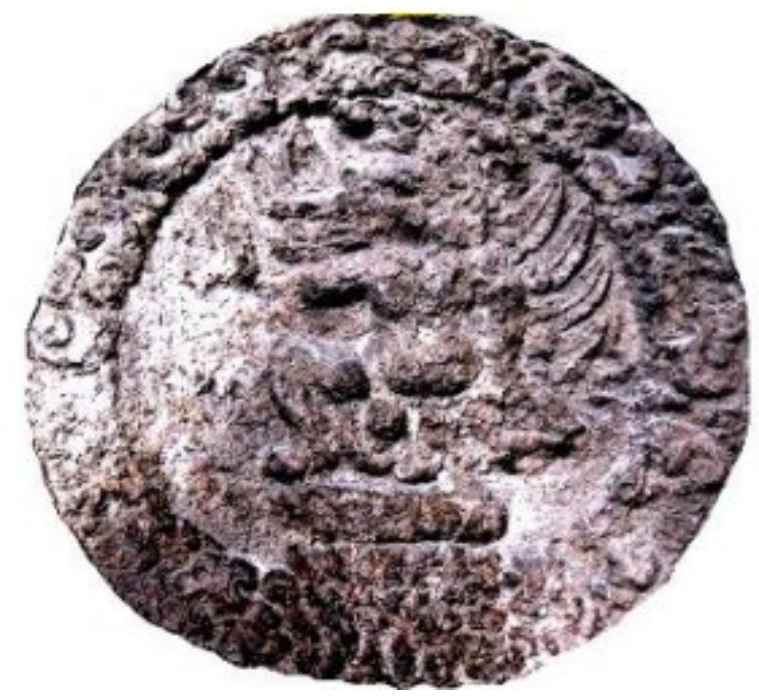

Sumber: Megakusuma 2013

Gambar 2 Lambang garudhamukhalañcana pada Prasasti Baru (952 Ś/1030 M)

Selain perhatian terhadap agama rși, Airlangga juga melakukan upaya-upaya pengembangan kegiatan religi masyarakatnya melalui penetapan simma untuk menunjang kegiatan ritual dan bangunan keagamaan lainnya, misalnya Prasasti Kusambyan yang menceritakan penetapan sima Desa Kusambyan untuk bertanggung jawab atas pemujaan rahyang iwak (Nastiti 2013), Prasasti Patakan yang menyebutkan penetapan sima Desa Patakan untuk memelihara bangunan suci Sang Hyang Patahunan, serta Prasasti Kamalagyan (959 Ś/1037 M) yang menyiratkan adanya usaha raja memastikan keamanan dan kenyamanan bangunan keagamaan berupa vīhara, kuți, dan pertapaan (Susanti 2010; Siswanto 2018). Upaya-upaya tersebut juga dapat diartikan sebagai cara Airlangga untuk menarik simpati kaum agamawan, sehingga kekuasaan Airlangga mendapatkan dukungan dari semua lapisan masyarakat. Lebih jauh lagi, dari bukti-bukti prasasti yang telah dibahas, terlihat adanya kebebasan masyarakat untuk memeluk agama apapun dan kegiatan agama tersebut juga didukung oleh raja.

\section{Gambaran Pertapaan Masa Jawa Kuno}

Pertapaan, atau dalam bahasa Jawa Kuno disebut patapān atau partapān, merupakan tempat sementara seseorang selama bertapa dalam jangka waktu tertentu (Munandar 1993). Pertapaan merupakan salah satu bentuk karsyan, yakni bangunan suci para rși dan pertapa, dengan karakteristik yaitu terdapat pratista sabha atau arca batu kecil yang diletakkan dalam punden terbuka (Munandar 1990). Selain karsyan patapān, disebutkan juga karsyan berbentuk mandala, atau biasa disebut kadewaguruan, yaitu kompleks perguruan bagi para rși dan pertapa yang lebih permanen di tempat yang jauh dari keramaian dengan karakteristik adanya pemujaan terhadap lingga-pranala (Munandar 1993).

Rși adalah pendeta-pertapa yang hidup dalam kesunyian dan jauh dari keramaian (Munandar 1990). Menurut Hariani Santiko (1990), kaum rși adalah mereka yang mengundurkan diri ke tempat sunyi untuk bertapa dengan tujuan menemukan kesempurnaan utama. Dalam masyarakat Jawa Kuno, kaum rși dan pertapa telah memasuki jenjang kehidupan (caturasrama) wanaprastha. Penyebutan agama Rși pertama kali ditemukan pada Prasasti Pucangan berbahasa Jawa Kuno (963 Śl1041 M) dan penyebutan 
tersebut juga sejajar dengan agama Hindu Saiwa, Waisnawa, dan Buddha (Susanti 2010). Sedangkan, kaum pertapa dapat diidentifikasi lebih jauh sejak masa Rakai Pikatan dari bukti Prasasti Siwagrha (778 Ś/856) yang menceritakan Rakai Pikatan yang mengundurkan diri menjadi pertapa setelah beberapa lama menjadi raja (de Casparis 1956). Pertapaan (patapān) juga telah disebutkan pada Prasasti Gandasuli II (Sang Hyang Wintang) yang diperkirakan berasal dari tahun $810 \mathrm{M}$, di mana dalam prasasti tersebut diceritakan penentuan batas-batas patapān Saiwa di hutan sebagai penunjang dharmma (Christie 1999).

Pertapaan digambarkan sebagai tempat yang terletak jauh dari keramaian, biasanya ada di hutan, lereng gunung, atau tepi pantai. P. J Zoetmulder (1983) menggunakan kakawin Lubdhaka karya Mpu Tanakung, yang berisi mengenai seorang pemburu bernama Lubdhaka yang melakukan ritual pemujaan kepada Siwa, untuk menggambarkan pertapaan. Menurut kakawin tersebut, pertapaan adalah tempat yang terletak di gunung dekat dengan hutan dan jurang, yang lembahnya dijadikan kebun dan sawah, serta terdapat juga sungai, kadewaguruan, dan candi yang sudah ditinggalkan. Prasasti Pucangan berbahasa Sanskerta (959 Ś/1032 M) juga menceritakan pembangunan pertapaan suci oleh Airlangga di lereng Gunung Pugawat, atau yang sekarang dapat diidentifikasi sebagai Gunung Penanggungan (Witasari 2009). Dapat disimpulkan bahwa pertapaan pada masa Jawa Kuno banyak dibangun di lereng-lereng pegunungan yang dianggap suci.

Mengenai komponen yang ada di pertapaan, Agus Aris Munandar dalam tesisnya tahun 1990 berjudul Kegiatan Keagamaan di Pawitra: Gunung Suci di Jawa Timur Abad 14-15, membahas mengenai temuan artefak dan fitur yang ada di Gunung Penanggungan, di mana Gunung Penanggungan sendiri telah disebutkan di Prasasti Cunggrang (851 Ś/929 M) sebagai dharmma karsyan pada masa Mpu Sindok. Agus Aris Munandar menjelaskan bahwa komponen karsyan berbentuk patapān, seperti yang ditemukan di Gunung Penanggungan, adalah arca-arca batu berbagai bentuk berukuran $0.5-1 \mathrm{~m}$, beberapa punden berundak sebagai tempat menyiapkan sesaji dan pemujaan oleh para rși dan pertapa, 10 serta dua buah batur dari batu polos yang diduga merupakan sisa pendopo terbuka sebagai tempat berkumpul dan menerima peziarah (Munandar 1990). Selain punden berundak dan batur, kegiatan bertapa juga dilakukan di gua-gua pertapaan yang dipakai sementara oleh pertapa. Gua-gua pertapaan sendiri ada yang memakai gua alami, seperti Gua Gunung Kombeng, Gua Kursi, dan gua-gua di Dieng; gua alami yang ditambah struktur baru misalnya Gua Tritis, Gua Lawa, dan Gua Kendalisada; serta gua buatan misalnya Gua Selamangleng Kediri dan Gua Selamangleng Tulungagung (Gambar 3) (Munandar dan Yulianto 1995).

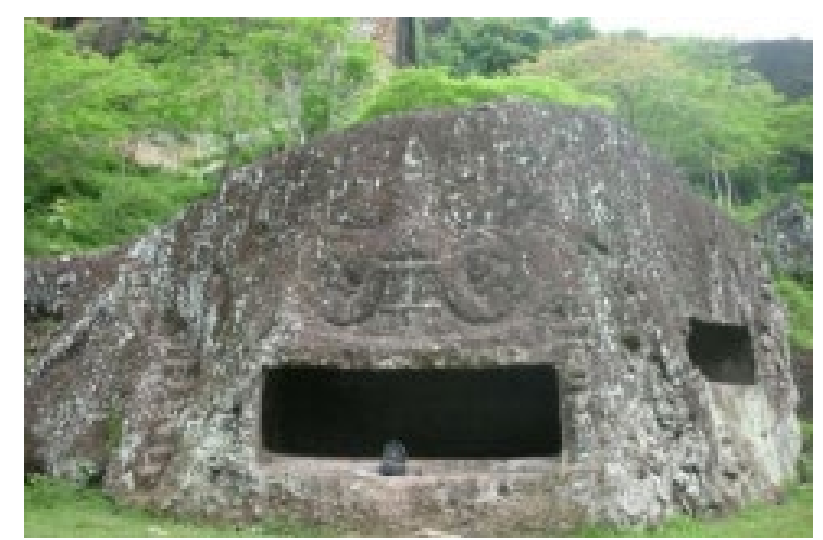

Sumber: Izza 2014

Gambar 3 Gua Selamangleng Tulungagung sebagai salah satu gua pertapaan masa Jawa Kuno

Bertapa adalah suatu usaha untuk mencapai tujuan tertentu. Bagi kaum rși, tapa memiliki tujuan untuk mencari kesempurnaan tertinggi melalui jalan kelepasan jiwa dan penyatuan dengan kebenaran utama (Rahayu 2016). Dalam sejarah kuno Indonesia, diketahui juga raja-raja melakukan tapa dengan tujuan tertentu. Berdasarkan Prasasti Pucangan berbahasa Jawa Kuno (963 Ś/1041 M) diceritakan bahwa saat peristiwa mahapralaya, Airlangga dan Narottama melarikan diri ke hutan Wanagiri dan hidup sebagai pertapa dengan tujuan untuk mengumpulkan kekuatan. Selama itu, ia selalu memuja dewa-dewi dengan keinginan untuk melindungi kerajaannya, menggantikan kedudukan leluhurnya, memperoleh kebahagiaan, memperbaiki semua bangunan suci dan menumpas kejahahatan di dunia (Munandar 1990). Dapat disimpulkan bahwa tapa dilakukan bukan hanya untuk tujuan religi, tapi juga tujuan lainnya misalnya politis, 
seperti mengumpulkan kekuatan, mendapatkan wahyu dan kharisma, dan memperoleh kemenangan.

\section{Latar Belakang Penetapan Sīma Bagi Pertapaan Pada Masa Pemerintahan Airlangga}

Bukti prasasti pada masa Airlangga menyebutkan adanya peristiwa penetapan sima bagi pertapaan yang disebutkan dalam tiga prasasti, yaitu Prasasti Terep I dan II (954 Ś/1032 M), Prasasti Turunhyang A (958 Ś/1036 M), dan Prasasti Pucangan berbahasa Jawa Kuno (963 Ś/1041 M). Prasasti Terep I dan II menceritakan mengenai penetapan status sima pertapaan di Tṛp yang dalam prasasti kedua lempeng pertama baris pertama berbunyi sebagai berikut:

"...kumonakan ikang patapān ri trp Imah kambang śrī thāni watěk pangkaja. padamlan sang hyang ajña praśasti tinanḍa garudamuka..."

Artinya: "memerintahkan pertapaan di Trp tanah Kambang Śrī desa yang masuk wilayah Pangkaja, agar dibuatkan Sang Hyang perintah raja berupa prasasti bertanda Garudamuka".

Penetapan juga dilakukan untuk sawah dan kebun sebagai penunjang kegiatan keagamaan disana (Wurjantoro 2018).

Selain itu, Prasasti Turunhyang A (958 Ś/1036 M) juga berisi perintah raja Airlangga untuk menetapkan Desa Turunhyang menjadi sima dan menyebutkan pembangunan pertapaan Śrī Wijayasirama sebagai tanda kesempurnaan bagi Sang Hyang Sarwwadharma yang menjadi bangunan suci sang cakrawartin. Anugerah tersebut diturunkan raja karena telah berhasil mengalahkan musuh-musuhnya (Susanti 2010). Prasasti Pucangan berbahasa Jawa Kuno (963 Ś/1041 M) juga menyebutkan penetapan Desa Barahem, Pucangan, dan Sapuri sebagai sima untuk menunjang pembangunan pertapaan sebagai tempat suci untuk mendirikan lingga, yang dalam prasasti pada baris ke-31 dan 32 disebutkan sebagai berikut:

"...madaměl yasa pa"

"tapan ing pucangan ista...s an rake yangken mantrastawa na mascara śrī bhattara hari sari, palingganan ikang rat..." (Yulianto 1996a).

Artinya: "membuat sebuah balai/rumah pertapaan di Pucangan....dipakai (mengucapkan) mantra- mantra pujian kepada Hari, dan sebuah tempat (suci untuk) lingga bagi dunia...." (Witasari 2009).

Dilihat dari tahun dikeluarkannya prasasti yang dihubungkan dengan tiga fase masa pemerintahan Airlangga, ketiga prasasti tersebut dikeluarkan pada fase konsolidasi dan fase keemasan. Dilihat juga dari alasan penetapan simanya (sambandha), maka terdapat dua faktor yang melatarbelakangi penetapan sima bagi pertapaan pada masa Airlangga, yaitu faktor politik dan faktor sosio-religi.

Faktor politik

Peristiwa serangan Haji Wurawari, atau dalam prasasti disebut mahapralaya, menyebabkan Airlangga harus melalui tantangan yang berat untuk menjadi raja. Peristiwa tersebut juga mempengaruhi awal masa pemerintahan Airlangga yang diwarnai dengan upaya penegakan hegemoni melalui penyerangan kepada musuhnya untuk menyatukan kerajaan. Banyak prasasti yang dikeluarkannya menceritakan upaya Airlangga bersama tentaranya menghadapi musuh sebelum akhirnya kerajaannya mencapai masa damai dan tenang. Selain memerangi musuh, penegakan hegemoni sebagai raja juga dilakukan dengan menarik simpati dari rakyatnya. Hal ini dimaksudkan untuk menunjukkan wibawanya sebagai raja yang baru, sehingga rakyat mengakui Airlangga sebagai raja. Pemberian anugerah sima kepada seseorang atau kelompok yang telah berjasa dibarengi dengan pemberian hak-hak istimewa menjadi salah satu upaya menanamkan legitimasinya sebagai raja (Susanti 2010).

Anugerah sima merupakan hal yang sakral pada masa Jawa Kuno. Hal ini disebabkan karena penetapan sima berarti mengubah status suatu tanah atau lahan, sebagai sumber hidup masyarakat menjadi status yang lebih tinggi dan suci. Kesakralan sima dapat dilihat dari upacara penetapannya yang dilakukan secara besarbesaran, melibatkan banyak orang dan menghabiskan banyak biaya. Prasasti juga menyebutkan ketentuan sima tidak dapat diganggu oleh siapapun dan yang berani mengganggu ketentuan tersebut akan terkena kutukan (Darmosoetopo 2003).

Jika dilihat dari konteks waktu dikeluarkannya prasasti dan dihubungkan dengan keadaan kerajaan Airlangga saat itu, penetapan sima bagi pertapaan, 
seperti yang terdapat pada Prasasti Terep I dan II (954 Ś/1032 M), Prasasti Turunhyang A (958 Ś/1036 M), dan Prasasti Pucangan berbahasa Jawa Kuno (963 Ś/1041 M) menjadi salah satu langkah Airlangga untuk menarik simpati dari rakyat, terutama golongan agamawan khususnya kaum rși dan pertapa. Dalam Prasasti Pucangan berbahasa Jawa Kuno (963 Ś/1041 M) diceritakan bahwa Airlangga dalam masa pengasingannya di hutan hidup sebagai seorang pertapa bersama abdinya, Narottama. Selama menjadi pertapa, Airlangga mempersiapkan dirinya secara fisik dan rohani, serta mengumpulkan pengikut-pengikut setia Dharmawangśa Tguh untuk menyerang musuh-musuhnya (Susanti 2010). Muncul suatu dugaan bahwa kaum rși merupakan kaum yang mendukung langkah-langkah Airlangga saat fase konsolidasi sebagai raja untuk menyatukan kerajaannya. Kaum rși senantiasa membantu Airlangga pada masa pengasingannya, sehingga dalam prasasti juga disebutkan bahwa pembangunan pertapaan di Gunung Pugawat dilakukan karena raja sudah mengucapkan nazar akan hal itu. Prasasti Terep I dan II (954 Ś/1032 M) dan Prasasti Turunhyang A (958 Ś/1036 M) juga dikeluarkan saat masa awal pemerintahan Airlangga yaitu fase konsolidasi kerajaan. Keterangan dari prasasti-prasasti tersebut menimbulkan suatu implikasi bahwa kaum agamawan, khususnya kaum rși memegang peran dan kedudukan penting pada masa Airlangga sehingga penetapan sima bagi pertapaan dan pembangunan pertapaan banyak dilakukan pada masa konsolidasi.

Seperti yang telah dijelaskan di bagian sebelumnya, agama memegang peranan penting dalam kehidupan masyarakat Jawa Kuno. Begitupun, dengan kedudukan dan peran dari kaum agamawan dan bangunan keagamaan bagi kerajaan. Agama Hindu mengenal sistem kasta dengan kaum agawaman menempati urutan paling atas dalam stratifikasi sosial. Kaum agamawan dianggap sebagai orang-orang suci yang memiliki pengetahuan yang tinggi, sehingga keberadaannya menjadi penting bagi kerajaan (Lombard 2018). Kedudukan dan peran penting dari kaum rși pada masa Airlangga dapat dilihat dari bukti Prasasti Baru (952 Ś/1030 M) yang menyebutkan agama rși untuk pertama kalinya. Agama rși juga diakui sebagai agama resmi kerajaan yang kedudukannya sejajar dengan agama Hindu, Buddha, dan Mahabrahmanā. Peran, kedudukan, dan pengaruh kaum agamawan dalam kehidupan bernegara menjadi alasan Airlangga merasa perlu untuk mendapatkan simpati dari kaum rși.

Bangunan keagamaan juga menjadi salah satu komponen penting dalam kerajaan. Melalui kaum agamawan dan bangunan keagamaan, raja dapat menjalankan upacara-upacara besar untuk mendapatkan legitimasi dan melanggengkan kekuasaannya. Selain itu, raja mendapatkan kharisma dan mempertahankannya melalui kegiatan tapa sehingga pertapaan menjadi bangunan suci keagamaan yang penting bagi raja (Christie 1983). Signifikansi kelompok agamawan dan bangunan kerajaan bagi pemerintahan suatu raja juga dapat dilihat pada masa pemerintahan Dyah Balitung (820830 S). Dalam Prasasti Wanua Tengah III (830 Ś/908 M) dijelaskan bahwa Balitung meneguhkan kembali status simma bihāra di Wanua Tengah dan memerintahkan semua bihāra di Jawa dijadikan swatantra. Upaya ini, menurut Kusen (1988), merupakan langkah politik Balitung untuk mendapatkan legitimasi dari kaum agamawan dan masyarakat Wanua Tengah karena dirinya bukan merupakan putra mahkota yang asli dan naik tahta karena perkawinan. Hal ini juga terjadi pada Airlangga, di mana upaya tersebut ditempuh sebagai bagian dari legitimasi Airlangga untuk mendapatkan dukungan dari kaum agamawan, dalam hal ini kaum rși, dan mendapatkan loyalitas dari penduduk Desa Pucangan, Barahem, Sapuri, Turunhyang, dan Kambang Śrī dengan cara memberikan hak istimewa melalui penetapan sima bagi pertapaan.

\section{Faktor sosio-religi}

Raja merupakan figur penghubung alam dewa dengan manusia yang mempunyai hak untuk memberikan anugerah kepada yang berjasa dan menghukum pelaku kejahatan. Anugerah raja tersebut salah satunya sima. Prasasti Terep I dan II (954 Ś/1032 M) menyebutkan pertapaan di Trp ditetapkan menjadi sima atas permintaan Rake Pangkaja Dyah Tumambong karena upayanya yang 
tanpa henti mendoakan kemenangan bagi raja. Oleh karena itu, raja menetapkan pertapaan di Tṛp sebagai rumah bagi arca bhātari menjadi sìma bersama dengan sawah dan kebunnya. Hal ini juga dilakukan oleh Airlangga, seperti yang diceritakan dalam Prasasti Turunhyang A (958 Ś/1036 M) bahwa Desa Turunhyang ditetapkan menjadi sima untuk pembangunan pertapaan Śrī Wijayaṡrama. Walaupun tidak disebutkan mengapa yang ditetapkan menjadi sima adalah Desa Turunhyang, namun dapat diidentifikasi bahwa desa ini memiliki jasa besar bagi kerajaan. Menurut Boechari (2012c) dilihat dari penetapan kembali Desa Turunhyang pada Prasasti Turunhyang $B$ masa pemerintahan Mapañji Garasakan, desa ini memiliki posisi yang strategis dan memiliki arti penting bagi kerajaan sebagai benteng raja dan/atau pendukung raja yang paling setia.

Berdasarkan kedua prasasti tersebut, dapat dikatakan bahwa penetapan simma bagi pertapaan merupakan bagian dari upaya Airlangga membalas jasa-jasa seseorang, kelompok, dan penduduk desa yang telah membantunya selama masa konsolidasi atau penyatuan kerajaan. Latar belakang tersebut juga didapatkan dari alasan penetapan prasasti-prasastinya yang sebagian besar merupakan balas jasa raja. Upaya balas jasa juga pernah dilakukan oleh Balitung (820-830 Ś) dalam Prasasti Mantyasih (827 Ś/915 M), di mana dia menganugerahkan sima bagi kelima patih dari Mantyasih karena telah berjasa menjaga perkawinannya (Boechari 2012a).

Selain faktor sosial, faktor religi juga menjadi latar belakang penetapan sima bagi pertapaan pada masa Airlangga. Kebijakan tersebut merupakan salah satu langkah Airlangga untuk memajukan kehidupan religi kerajaannya, khususnya kehidupan religi kaum rși dan pertapa. Langkah tersebut dilakukan Airlangga untuk menjamin keberlangsungan kehidupan dan upacara keagamaan dari bangunan suci. Prasasti Terep I dan II (954 Ś/1032 M) menyebutkan bahwa tiga sawah ditetapkan sebagai penunjang pertapaan di Trp, yaitu sawah di sebelah utara, timur, dan sawah di Wuntalan yang masing-masing luasnya 1 tampah, serta kebun di sirih pinang di timur Babad Hampu yang berukuran 2 tampah sawah. Prasasti Turunhyang A (958 Ś/1036 M) juga menyebutkan sawah sebagai penunjang pertapaan Śrī Wijayaṡrama yang hasilnya sebesar emas 2 suwarna, serta kebun, yang luas sebelah utara dan selatannya 118 dpa dan luas timur dan baratnya 90 dpa (Yulianto 1996a; Siswanto 2018).

Menurut Riboet Darmosoetopo (2003), pendapatan tanah sima digunakan untuk pemeliharaan bangunan keagamaan dan mendukung kegiatan ritual, seperti menyediakan persembahan dan saji-sajian, serta untuk menunjang kehidupan golongan agamawan sebagai pengelola bangunan suci. Adapun pembagian pendapatan dari tanah sima, yaitu kerajaan mendapatkan sepertiga, bangunan keagamaan sepertiga, dan sepertiga lagi diserahkan kepada kepala sima (Darmosoetopo 2003). Ketersediaan sima sebagai dana penunjang bangunan suci, khususnya pertapaan, bertujuan untuk memantapkan kelestariannya dari waktu ke waktu sebagai elemen penting dalam kerajaan.

\section{PENUTUP}

Kebijakan seorang raja tidak dapat terlepas dari kondisi kehidupan kerajaannya. Begitupun dengan kebijakan Airlangga untuk menetapkan sima bagi pertapaan pada masa pemerintahannya yang disebutkan dalam Prasasti Terep I dan II (954 Ś/1032 M), Prasasti Turunhyang A (958 Ś/1036 M), dan Prasasti Pucangan berbahasa Jawa Kuno (963 Ś/1041 M). Penetapan sima dan anugerah raja merupakan dua hal yang tidak dapat dilepaskan. Raja memberikan anugerahnya berupa sima karena latar belakang tertentu. Penetapan sima bagi pertapaan pada masa Airlangga tidak terlepas dari langkah politiknya sebagai raja baru untuk mengumpulkan dukungan dari rakyatnya, khususnya kaum rși, yang diduga memiliki kedudukan penting dalam struktur sosial masyarakat masa itu. Upaya ini digunakan oleh Airlangga, sebagai raja baru, untuk melancarkan relasi baiknya dengan golongan-golongan yang berpengaruh di masyarakat. Langkah politik ini sejalan dengan data-data lainnya yang mengindikasikan upaya legitimasi Airlangga sebagai raja, misalnya konsep-konsep keagamaan yang dianut oleh Airlangga, seperti kultus dewa raja dengan sifat-sifat kedewaannya yang baik dan murah hati. 
Selain itu, balas jasa terhadap pengikutnya yang setia juga menjadi latar belakang penetapan sima bagi pertapaan. Hal ini berhubungan dengan konsep cakravarttin, di mana Airlangga digambarkan sebagai seorang raja yang murah hati, bermoral baik, dan memberikan ketentraman, kenyamanan, dan anugerah bagi masyarakatnya.
Konsep ini juga menekankan raja sebagai tokoh yang dapat menjadi "payung" dan memberikan kesejahteraan kepada rakyatnya. Perwujudan konsep ini sejalan dengan upaya Airlangga menetapkan sima bagi pertapaan untuk mendukung kehidupan rohani dan sebagai penunjang ritual keagamaan pada bangunan suci.

\section{DAFTAR PUSTAKA}

Bakker, J. W. M. 1972. IImu Prasasti Indonesia. Edisi keempat. Yogyakarta: Jurusan Sedjarah Budaya IKIP Sanata Dharma.

Boechari. 1985/1986. Prasasti Koleksi Museum Nasional Jilid I. Jakarta: Proyek Pengembangan Museum Nasional.

Boechari. 2012a. "Epigrafi dan Sejarah Indonesia". hlm. 3-28 dalam Melacak Sejarah Kuno Indonesia Lewat Prasasti, Tracing Ancient Indonesian History through Inscriptions, editor A. Griffiths, N. Susanti, H. Djafar, dan E. Wurjantoro. Jakarta: Penerbit Kepustakaan Populer Gramedia.

Boechari. 2012b. "Rakryān Mahāmantri I Hino Śrī Sanggrāmawijaya

Dharmaprasādottunggadewi". hlm. 71-102 dalam Melacak Sejarah Kuno Indonesia Lewat Prasasti, Tracing Ancient Indonesian History through Inscriptions, editor A. Griffiths, N. Susanti, H. Djafar, dan E. Wurjantoro. Jakarta: Penerbit Kepusatakaan Populer Gramedia.

Boechari. 2012c. "Śrī Mahārāja Mapañji Garasakan: New Evidence on the Problem of Airlangga's Partition of His Kingdom". hlm. 135-54 dalam Melacak Sejarah Kuno Indonesia Lewat Prasasti, Tracing Ancient Indonesian History through Inscriptions, editor A. Griffiths, N. Susanti, H. Djafar, dan E. Wurjantoro. Jakarta: Penerbit Kepusatakaan Populer Gramedia.

Brandes, J. L. A. 1913. Oud-Javaansche Oorkonden, Nagelaten Transcripties. Batavia dan 's Hage: Albrecht \& Co. dan M. Nijhoff.

de Casparis, J. 1956. Prasasti Indonesia II. Bandung: Dinas Purbakala Republik Indonesia.

de Casparis, J. 1958. "Airlangga". Pidato Pengukuhan Guru Besar Indonesia Sedjarah Lama dan Bahasa Sanskerta, 26 April 1958. Malang: Universitas Airlangga.

Christie, Jan Wisseman. 1983. "Rāja and Rāma: The Classical State in Early Java". hIm. 9-44 dalam Centers, Symbols, and Hierarchies: Essays on the Classical States of Southeast Asia, editor L. Gesick dan C. Geertz. Connecticut: Yale University Southeast Asia Studies.

Christie, Jan Wisseman. 1999. Register of the Inscriptions of Java Volume II (The Inscriptions of Mataram). Working draft.

Darmosoetopo, Riboet. 2003. Sima dan Bangunan Keagamaan di Jawa Abad IX-X TU. Yogyakarta: Penerbit Prana Pena.

Dwiyanto, Djoko. 2018. Refleksi Penelitian Epigrafi dan Prospek Pengembangannya. Yogyakarta: Kepel Press.

Hall, Kenneth R. 2011. A History of Early Southeast Asia: Maritime Trade and Societal Development, 100-1500. Lanham: Rowman \& Littlefield Publishers, Inc.

Izza, Nainunis Aulia. 2014. "Gaya Arsitektur Gua Selomangleng Tulungagung sebagai Pertapaan Masa Mataram Kuno Jawa Bagian Timur dan Muatan Pendidikannya". Jurnal Sejarah dan Budaya 8(2):176-191. 
Jones, Antoinette M. Barret. 1984. Early Tenth Century Java Form The Inscriptions. Leiden: Foris Publications.

Julianto, Ninie Susanti. 2012. "Dharmawangsa Tguh Dan Airlangga". hlm. 190-95 in Indonesia dalam Arus Sejarah 2: Kerajaan Hindu-Buddha, editor T. Abdullah dan A. B. Lapian. Jakarta: PT Ichtiar Bau van Hoeve bekerja sama dengan Kementrian Pendidikan dan Kebudayaan Republik Indonesia.

Kusen. 1988. Faktor - Faktor Penyebab Terjadinya Perubahan Status Sawah Di Wanua Tengah Dalam Masa Pemerintahan Raja - Raja Mataram Kuna Abad 8 - 10. Laporan Penelitian Arkeologi. Yogyakarta: Fakultas Sastra Universitas Gadjah Mada.

Lombard, Denys. 2018. Nusa Jawa Silang Budaya Bagian III: Warisan Kerajaan-Kerajaan Konsentris. Edisi Revisi. Jakarta: PT Gramedia Pustaka Utama.

Megakusuma, Bintang. 2013. "Prasasti "Garudhamukha" 945 Śaka". Skripsi. Depok: Universitas Indonesia.

Munandar, Agus Aris. 1990. "Kegiatan Keagamaan di Pawitra: Gunung Suci di Jawa Timur Abad 14-15". Tesis. Depok: Universitas Indonesia.

Munandar, Agus Aris. 1993. Gunung Penanggungan sebagai Tempat Kegiatan Kaum Rsi. Laporan Penelitian Arkeologi. Depok: Universitas Indonesia.

Munandar, Agus Aris, dan Kresno Yulianto. 1995. Arsitektur Gua sebagai Sarana Peribadatan. Laporan Penelitian Arkeologi. Depok: Universitas Indonesia.

Nasoichah, Churmatin. 2017. "Pembacaan Angka Tahun Prasasti Sirah Kĕting dan Kaitannya dengan Tokoh Śrī Jayawarsa Digwijaya Śastraprabhu". Purbawidya 6(1):1-18.

Nastiti, Titi Surti. 2013. "Prasasti Kusambyan: Identifikasi Lokasi Madander dan Kusambyan". Amerta 31(1):69-79.

Nugroho, Aang Pambudi. 2015. "Penelusuran Beberapa Fragmen Prasasti Paṇ̂ān Di Rumah Penduduk (Desa Pandankrajan, Kecamatan Kemlagi, Kabupaten Mojokerto)". Berkala Arkeologi 35(1):73-90.

Poesponegoro, Marwati Djoenod, and Nugroho Notosusanto, eds. 2008. Sejarah Nasional Indonesia II, Zaman Kuno. Edisi
Pemutakhiran. Jakarta: Balai Pustaka.

Rahayu, Andriyati. 2016. "Kehidupan Kaum Agamawan Masa Majapahit Akhir: Tinjauan Epigrafis". Disertasi. Depok: Fakultas IImu Pengetahuan Budaya Universitas Indonesia.

Santiko, Hariani. 1990. "Kehidupan Beragama

Golongan Rsi Di Jawa". hlm. 156-71 dalam

Monumen: Karya Persembahan untuk Prof.Dr.R. Soekmono, editor E. Sedyawati, I. H. . Pojoh, dan S. Rahardjo. Depok: Fakultas Sastra Universitas Indonesia.

Sedyawati, Edi. 1985. "Pengarcaan Ganesha Masa

Kadiri Dan Singhasari: Sebuah Tinjauan

Sejarah Kesenian". Disertasi. Jakarta: Universitas Indonesia.

Setyawatiningrum, Murni. 2016. "Peranan Jawa Dalam Perdagangan Emporia Asia Abad X-XI Masehi". Skripsi. Yogyakarta: Universitas Gadjah Mada.

Siswanto. 2018. "Identifikasi Penggunaan Lahan Berdasarkan Sumber Prasasti Abad Ke-11 Masehi Di Jawa Timur". Purbawidya 7(1):2134.

Suarbhawa, I Gusti Made. 2000. "Teknik Analisis Prasasti". Forum Arkeologi (II):135-47.

Susanti, Ninie. 2010. Airlangga: Biografi Raja Pembaru Jawa Abad XI. Depok: Komunitas Bambu.

Witasari, Vernika Hapri. 2009. "Pasasti Pucangan Sansekerta 959 Śaka (Suatu Kajian Ulang)". Skripsi. Depok: Universitas Indonesia.

Witasari, Vernika Hapri. 2011. "Lambang Raja Pada Kerajaan Kuna Di Kawasan Indonesia Abad XI-XV Masehi: Sebuah Rekonstruksi Makna". Tesis. Depok: Universitas Indonesia.

Wurjantoro, Edhie. 2018. Anugerah Sri Maharaja, Kumpulan Alihaksara dan Alihbahasa Prasasti-Prasasti Jawa Kuna dari Abad VIII$X I$. Depok: Fakultas IImu Pengetahuan Budaya Universitas Indonesia.

Yulianto, Ninie Susanti. 1996a. Prasasti-Prasasti Sekitar Masa Pemerintahan Raja Airlangga: Suatu Kajian Analitis. Laporan Penelitian Arkeologi. Depok: Universitas Indonesia.

Yulianto, Ninie Susanti. 1996b. Prasasti Sebagai Data Sejarah Kuna. Laporan Penelitian Arkeologi. Depok: Universitas Indonesia.

Zoetmulder, P. J. 1983. Kalangwan, Sastra Jawa Kuno Selayang Pandang. Jakarta: Penerbit 
Latar Belakang Penetapan Sima bagi Pertapaan pada Masa Pemerintahan Airlangga (1019-1043 M)- Yori Akbar Setiyawan (1-16)

Doi: $10.24832 / k e . v 7 i 1.84$

Djambatan.

Zoetmulder, P. J., dan S. O. Robson. 1995. Kamus

Kepusatakaan Populer Gramedia.

Jawa Kuna-Indonesia. Jakarta: Penerbit 